\title{
The metaphor of light embedded in the Johannine prologue, Part 2: The Light at and after the incarnation
}

\author{
Authors: \\ Dirk G. van der Merwe ${ }^{1}$ \\ Pierre Y. Albalaa ${ }^{1}$ \\ Affiliation: \\ ${ }^{1}$ Department of Christian \\ Spirituality, Church History \\ and Missiology, University of \\ South Africa, South Africa \\ Correspondence to: \\ Dirk van der Merwe \\ Email: \\ dirkvdm7@gmail.com \\ Postal address: \\ 189 Kotie Ave., Murrayfield \\ 0184, Pretoria, South Africa \\ Dates: \\ Received: 12 Mar. 2012 \\ Accepted: 02 July 2012 \\ Published: 26 Aug. 2013 \\ How to cite this article: \\ Van der Merwe, D.G. \& \\ Albalaa, P.Y., 2013, 'The \\ metaphor of light embedded \\ in the Johannine prologue, \\ Part 2: The Light at and \\ after the incarnation', In die \\ Skriflig/In Luce Verbi 47(1), \\ Art. \#173, 9 pages, http:// \\ dx.doi.org/10.4102/ids. \\ v47i1.173 \\ Note: \\ Pierre Y. Albalaa was a \\ research associate of Prof. \\ Dirk G. van der Merwe in \\ the Department of New \\ Testament at the University \\ of South Africa.
}

\section{Copyright:}

(C) 2013. The Authors.

Licensee: AOSIS

OpenJournals. This work

is licensed under the

Creative Commons

Attribution License.
Read online:

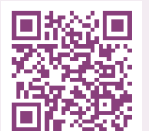

Scan this QR code with your smart phone or mobile device to read online.
This is the second of two articles on how the fourth evangelist has embedded the light metaphor in the prologue of the Fourth Gospel. The prologue is replete with this metaphor. A thorough discourse analysis explores the text's inner texture to determine the rhetoric and network of semantic relations - regarding light as the subject. From here the text's sacred texture is investigated. Various theological themes are interwoven into the text, with light being a consistent, embedded metaphor, embracing a wealth of facets and interpretations. This research focuses on the embedded light metaphor in the Johannine prologue as it relates to the Word's performance during and after the incarnation.

Die metafoor van lig ingebed in die Johannese proloog, Deel 2: Die Lig tydens en na die inkarnasie. Hierdie is die tweede van twee artikels om aan te toon hoe die vierde evangelis die lig-metafoor in die proloog van die Vierde Evangelie ingebed het. Die proloog is deurdrenk met hierdie metafoor. Deur middel van 'n behoorlike diskoersanalise is die diepte-struktuur van die teks ondersoek om die retoriek en netwerk van semantiese verhoudings vanaf die perspektief van lig as onderwerp te bepaal. Hierna is die teologiese struktuur van die teks ondersoek. Verskeie teologiese temas is in die teks verweef, met 'lig' as 'n konstante verankerde metafoor wat 'n rykdom van fasette en interpretasie insluit. Hierdie navorsing fokus op die ingebedheid van die lig-metafoor in die Johannese proloog soos wat dit verband hou met die funksionering van die Woord tydens en na die inkarnasie.

\section{Introduction}

The prologue of the Gospel of John is one of the most studied texts of early Christian writings (see for example, De Wolf 1960; Ryan 1963; Brown 1965; Cahill 1976; Miller 1977; Staley 1986; Waetjen 2001; Deeks 2002; Hildegard \& Newman 2003; Riches 2005; Boismard 1953; LaMarche 1997; Borgen 1970; Hooker 1970; Culpepper 1981; Van der Watt 1995). It takes the reader from the 'world above', the realm of God and the Logos, to the 'world below', the world of human history, and back again to the 'world above' into the bosom of the Father. The prologue of the Fourth Gospel (hereafter FG) presents a summary account of the activity of the pre-existent Logos in its vocational fulfilment as the divine agent of creation and communication. It describes the background against which Jesus's historical self-disclosure must be understood. The prologue can be seen as a splendidly constructed $a$ priori introduction to the gospel concerning Jesus Christ (Schnackenburg [1968] 1980:221; Ridderbos 1997:17; cf. also Malina \& Rohrbauch 1998:30). Right from the beginning, the being of Jesus and the significance of his work are placed in the context of the Logos, which was with God in the beginning and to which all created things owe their existence and sinners owe their salvation. In the prologue Jesus is also referred to as Life and Light. This Logos came into the world as Jesus, became flesh in him, dwelled amongst people and was beheld in all its glory by those who saw him.

This research emphasises the positive theological exposition of the prologue from the perspective of the customary light concept. ${ }^{1}$ The objective is firstly to indicate the comprehensive embeddedness of the light metaphor in the Johannine prologue, and secondly to highlight the many features of the light metaphor. Finally, this investigation shows how the light metaphor connects major themes in the prologue - light being one of the key theological themes of the prologue. The focus in this research will be on how the Logos is described to function as the Light during and after the incarnation. ${ }^{2}$

A dual approach will be followed: (1) an inner-textural reading of the text to identify the various semantic overtones regarding the light metaphor, and to structure the research, and (2) a sacred-

1.This is the second article in a series of two to point out how the fourth evangelist has embedded the light metaphor in the prologue of the Fourth Gospel. The title of the first article is: 'The metaphor of light embedded in the Johannine prologue. Part 1: The Light before the incarnation'.

2.In the first article the focus is on the references to the light metaphor in the Johannine prologue prior to the incarnation. In this article the focus is on the references to the light metaphor during and after the incarnation. 
textural reading to correlate and interpret these semantic overtones. ${ }^{3}$

\section{An inner-textural and sacred- textural reading of the prologue}

Due to the similar nature and presentation of the two related articles - (1) 'The metaphor of light embedded in the Johannine prologue, Part 1: The Light before the incarnation' and (2) 'The metaphor of light embedded in the Johannine prologue, Part 2: The Light during and after the incarnation' - the content of subsections 'An orientation to inner-textural and sacred-textural reading' and 'The inner-textural reading of the Johannine prologue' in both is exactly the same. Therefore, these two subsections will not be repeated in this article. The discourse analysis will be included to make it convenient for the reader to follow the research. For more see the addendum.

\section{A theological-textural reading of the discourse analysis of the prologue}

The following is a discussion of the semantic relations indicated above and their theological meaning and implications from the perspective that Jesus Christ, the only Son of God, is the Logos or Light, who came to reveal (enlighten) and to save (lighten).

\section{The Word or Light came into the world (cluster a)}

This section concentrates on the incarnation of the Logos or Light and the mode of the incarnation.

\section{Semantic relations:}

1.1 'Ev $\dot{\alpha} \rho \chi \tilde{\eta} \ldots . . . . \underline{\tilde{\eta}} \mathbf{v} \dot{o} \lambda \dot{o} \gamma o \sigma_{\text {, }}$

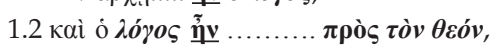

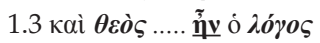

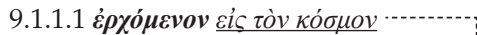

$10.1 \ldots \ldots \ldots \ldots \ldots \ldots \dot{\varepsilon} v \tau \tilde{\omega} \kappa o ́ \sigma \mu \omega \tilde{\eta} v$,

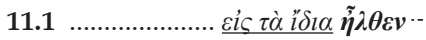

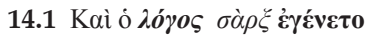

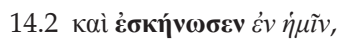

The four references to Jesus's coming into the world in 9.1.1.1, 10.1, 11.1 and 14.1 culminate in 14.1. With the first three vague phrases referring to 'coming into the world', ${ }^{4}$ the Fourth Evangelist (hereafter, FE) prepares the reader for the incarnation of the Light or light in 14.1. How precisely the Light or light comes into the world remains unsaid. Verse 14 first makes it clear that it took place in an unexpected

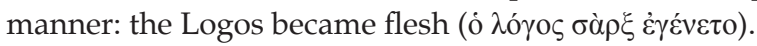

3.The inner-textural and sacred-textural readings of a text are textures used in the socio-rhetorical methodology as developed by Vernon Robbins (Robbins 1996). Another scholar, Duane Watson, is working in collaboration with Robbins on this methodology. In my usage of this terminology I do not comply with the way Robbin and Watson use it. For us it is just an indication and reference to work with the text (inner-texture) and the theological discourse (sacred-texture) generated by the text (inner-texture) and the theological discourse (sacred-texture) generated by the approaches that will be exploited in this research.

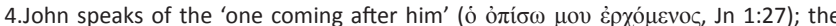

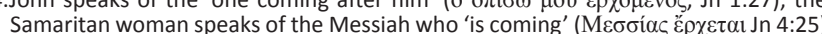
and who will explain all things; Martha proclaims her faith in Jesus as 'the Messiah,

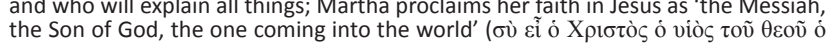

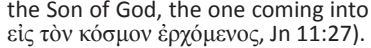

Interpretation of the semantic related texts: In contrast to John 'the Baptist' (Jn 1:8), who was merely a 'lamp' (Jn 5:35),

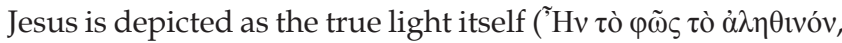
9.1) (Keener 2003:393). The reference 'coming into the world'

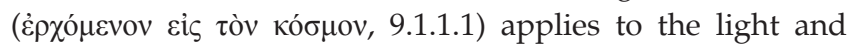
refers to the incarnation. It is an apt Johannine depiction of Jesus in view of the common application to him of $\dot{\varepsilon} \rho \chi 0$ $\mu \varepsilon v o \varsigma^{5}$ The hope of Israel was focused on the one coming into the

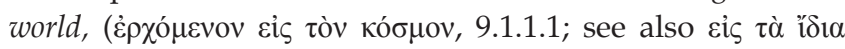
$\tilde{\eta} \lambda \theta \varepsilon v, 11.1$ ), a phrase canonised in messianic expectation. ${ }^{6}$ The 'coming' of the light refers not only to the moment of its arrival but also to its proximity and accessibility that result from that coming and by which every person has come within reach of the light (Ridderbos 1997:43).

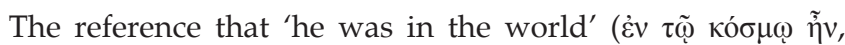
10.1) could indicate the presence of the Logos or Light in the dwelling place of men, and then takes on the meaning of 'the world of man'. This would mean that he was so close to men that they could reach him, even cleave to him for their salvation (Schnackenburg [1968]1980:255). The prior reference to John in verses 6-8 and the continuation of this thought (10.1) make clear that the mission of the incarnate Logos is already in focus, although the incarnation will only explicitly be mentioned in verse 14 . The Logos was not only the fundamental and universal principle of light in the divine plan, but he also illumined the existence and way of man from within the historical reality of man's environment or 'world' (Schnackenburg [1968]1980:255). Unfortunately, the leading circles of the Jews remain somewhat stubborn 'without understanding (cf. Jn 8:14, 19; 9:29; also 8:28, 43) and indeed blind (Jn 9:39) when confronted with the "light of the world"' (Schnackenburg [1968]1980:258). The coming of the light occasions a division in Israel (Jn 3:19-21). The 'world', the 'Judeans', even Jesus's 'own' will not receive the light (Jesus) (Jn 1:10f; 3:19) (Malina \& Rohrbauch 1998:32). ${ }^{7}$ Thus the first three references in the semantc relations $(1.1,1.2,1.3)$ follow one another in a climbing logical sequence.

It is only in 14.1 that the FE again refers to the incarnation ${ }^{8}$

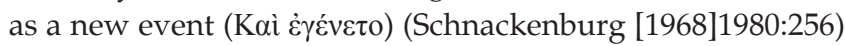
and explains this event. The Logos of God became $\sigma \grave{\alpha} \rho \xi$

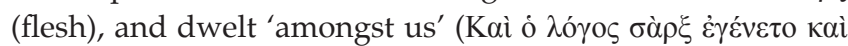
$\dot{\varepsilon} \sigma \kappa \eta \dot{v} \omega \sigma \varepsilon v \dot{\varepsilon} v \dot{\eta} \mu \mathrm{i} v)$. Here, the incarnation reaches a climax; hence, divine and human polarities are held together in one person (Schnackenburg [1968]1980:266). Whereas in the first part of the prologue the divine presence of the Word as the light of the world is emphasised, now the focus shifts to the self-identification of the Word with the man Jesus (cf. Petersen 1993:14). By means of incarnation, God has now visibly appeared amongst humankind. The flesh is the medium of the glory and makes it visible to all people.

\footnotetext{
5.See John 1:15, 27; 3:31; 6:14; 11:27; 12:13; Hebrews 10:37; 2 John 7; Revelations 1:4.

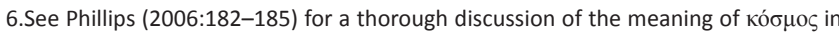
this context.

7.See also Ridderbos (1997:44f.) for an explanation of 'world' and 'his own'.
}

8.See Keener (2003:406-408) for an inner-textural discussion of 'the Word's incarnation'. 
The explicit mention of Logos in verse 14 links it with verse 1 and forms a multiple contrast with verse $1,{ }^{9}$ although verse 1 also serves as a commentary on verse 14 . Both verses have a double $\kappa \alpha i$ and highlight the contrast: ${ }^{10}$

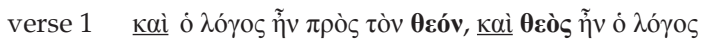

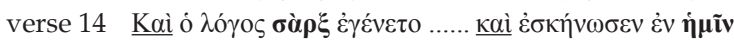

Logos in the presence of God (expressed by $\pi \rho$ ò $\varsigma$ ) is contrasted with the finite, earth-bound, death-destined oஷ̀ $\rho \xi$ [flesh]. The eternal pre-existence (expressed by $\tilde{\eta} v$ ) is contrasted with the

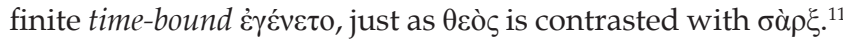

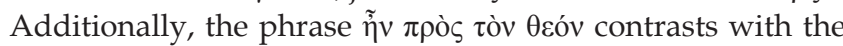

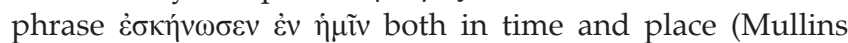
2003:68). Although the $\sigma \grave{\alpha} \rho \xi$ contrasts so radically with Logos, the glory $\left(\delta \delta^{\prime} \xi \alpha, 14.3\right)$ is now seen through the $\sigma \grave{\alpha} \rho \xi$; the glory is sensible to sensory human experience in the $\sigma \alpha \dot{\rho} \xi$ of Jesus, who informs his disciples: 'Anyone who has seen

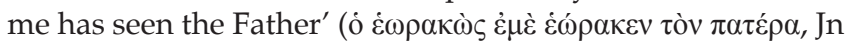
14:9). The Light or light became sensible, in the sense of being capable of being apprehended by the senses or perceptible to the mind.

Conclusion: In this section we have discussed how the FE prepared the reader in three references $(9.1 .1 .1 ; 10.1 ; 11.1)$ for the realisation of the incarnation in verse 14 . In verse 14 the incarnation is clearly contrasted with heavenly transcendence (verse 1). The Logos, who was with God in the beginning, came into the world as light (glory) and 'tabernacled' in this world.

\section{The True Light enlightens everyone - his glory could be seen (cluster e)}

The previous section was about the Logos or Light, who came into the world $(9.1 .1 .1 ; 10.1)$, and became 'flesh' $(14.1,2)$. This section will take it consecutively further and reflect on the experience of the Light and the reason for its coming. It seems as if verse 5.1 prepares the reader for what is said in verses 14 and 16-17.

\section{Semantic relations:}

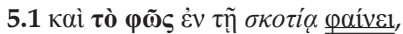

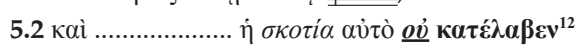

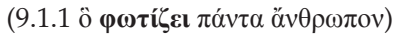

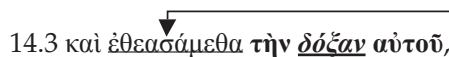

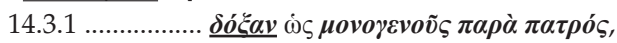

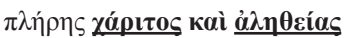

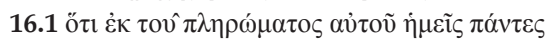

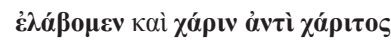

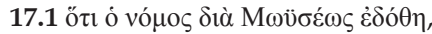

17.2

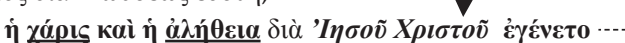

9. Hence, in comparison with verse 1 , verse 14 : 'expresses the unmistakable paradox that the Logos who dwelt with God, clothed in the full majesty and glory of the divinity and possessing the fullness of the divine life, entered the sphere of the earthly and human, the material and perishable, by becoming flesh'(Schnackenburg [1968]1980:266).

10.For Köstenberger (2004:41) the incarnation represents an event of equal importance with creation.

11.Its Johannine usage expresses 'which is earth-bound (3:6), transient and perishable (6:63), the typical human mode of being, as it were, in contrast to all perishable (6:63), the typical human mode of being, as it were

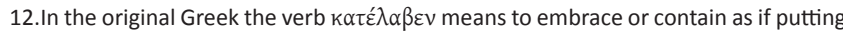
one's arms around it; an action, which can be done with good intentions (a friendly embrace) or with hostility (the action of smothering or crushing someone).
In these phrases a number of semantic relations can be found with $\delta$ '́ $\xi \alpha$ at the centre. The focus here is the experience of the glory of the Light. The experience of the Light or light and the reason for its coming are described in three verbs:

paiveı describes the reality that the light (glory) shines

$\dot{\varepsilon} \lambda \dot{\alpha} \beta$ o $\mu \varepsilon v$ refers to the reception of the glory

$\dot{\varepsilon} \gamma \varepsilon \dot{\varepsilon \varepsilon \tau 0^{13}}$ refers to the giving of the 'grace and truth' (glory)

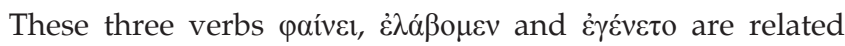
due to the fact that they belong to the same semantic field of 'revelation' or even 'enlightenment'. The FE describes repeatedly the nature of the experience and reason for its

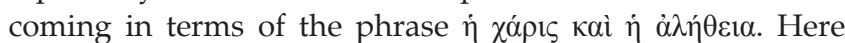
Jesus, tò $\varphi \tilde{\omega} \zeta$, is referred to as having the $\delta$ ó $\xi \alpha v$, which is characterised as $\chi \alpha$ ó gives to those who believe in him (Jn 17:2).

Interpretation of the semantic related texts: Verse 5 introduces the light or darkness dualism which occurs throughout the Gospel of John. ${ }^{14}$ Both light (Jn 1:4, 5, 7, 8, 9; $3: 19-21 ; 5: 35 ; 8: 12 ; 9: 5 ; 11: 9,10 ; 12: 35,36,46)$ and day (Jn 9:4), darkness (Jn 1:5; 3:19; 8:12; 12:35, 46) and night (Jn 9:4; 11:10) appear regularly throughout the Gospel. The antithesis in verse 5 was a typical rhetorical form in Greek and Jewish thought. ${ }^{15}$ If a person walks in the light they will never be overcome by darkness (Keener 2003:387, 382).

It seems as if the FE was also influenced by the Jewish literature which portrays both Wisdom and Torah as light (Ps 119:105, 130; Pr 6:23). Jesus as God's Word, Wisdom and Torah is light to enlighten the people of God, similar to the Torah being light offered to the people of God at Sinai. 'Light of people' (Jn 1:4) relates to 'light for humanity' (Jn 3:19), 'light for the world' (Jn 9:5). In the prologue of John this light relates to glory (verse 14), as is the case in Revelations 18:1 and 21:23 (Keener 2003:385).

Therefore the FE states it comprehensibly in the prologue that the Logos (the Light) became a human being to enlighten the world. ${ }^{16}$ He came into the world as light (Jn 3:19; 12:46; 8:12). The light was certainly 'in the world' (Jn 1:10) in this context and the entrance of light to which John testifies according to the prologue (verses 6-8 and 15) is the incarnate Logos, whose incarnation is depicted as a new Sinai theophany ${ }^{17}$ in verses $14-18$. The guiding imagery for verses $14-18$ comes from Exodus 33-34 (cf. also Ex 26). This would reinforce the wilderness background of the image of God's presence

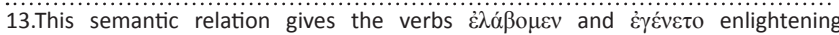
(illuminating) status.

14.According to Keener (2003:382) this dualism, which figures heavily in Gnosticism, is no less pervasive in earlier sources. He refers to a few philosophers who spoke of true knowledge as providing light. For example, Seneca Ep. Lucil. 48.8 (lumen), Plutarch Lect 17 and cf. Philo Creation 53. Also see Acts 17:27; 26:18; Ephesians $4: 18$

15.See Keener (2003:386) for verifications of this statement.

16.Philo regards God as light and the archetype of all other kinds of light (Philo Dreams 1.75, from Ps 27:1; Alleg. Interp. 3.25-26; Planting 9). See Keener (2003:383f.) for a thorough discussion of the figurative use of light in the OT and the common application of the contrast of light and darkness with good and evil respectively.

17.See Beasley-Murray (2002:14). Ridderbos (1997:53) points out that no transfiguration occurs in the FG and therefore does not refer the incarnation and glory of the Logos to any single sensational event. That glory is attendant on the glory of the Logos to any single sensational event. That glory is attendant on the
dwelling, just as in the Old Testament a persistent connection exists between God's dwelling, just as in the Old Testament a persistent connection exists between God's
presence in the tabernacle and temple and the divine kabod revealing itself there. 
amongst his people. ${ }^{18}$ Here at Mount Sinai, for a second time in the context of giving the Torah, God revealed his character ('glory') to Moses. In this context 'glory' alludes to the revelation of God to Moses in Exodus 33-34, which could also be pictured as shining (cf. Ex 34:29; Keener 2003:412). As in Exodus, the Word came to God's people. According to the $\mathrm{FE}$ he is the one who tabernacles ${ }^{19}$ amongst his people and whose glory is revealed; he is the Word. Here (as in 2 Cor 3), not $^{20}$ Moses but eyewitnesses of Jesus behold and testify to God's glory (Keener 2003:405). Jewish readers, with such a complex of concepts, would have known that 'glory' refers to a revelation of God's character, as implied in Exodus 33-34 (see especially Ex 33:19; 34:6-7). ${ }^{21}$

'Glory' as well as 'grace and truth' have been received by others from him. In verse 14 Logos is the antecedent of the personal pronoun his ( $\alpha \dot{\tau} \tau o \tilde{v})$. Hence, glory ( $\delta$ ' $\xi \alpha v)$ is the quality of the Logos. However, in 14.3.1 the noun 'glory' is frequent, but now in relation to the 'only Son from the

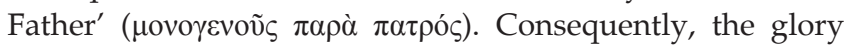
of the Logos is experienced in Jesus, but as the 'glory of the only Son from the Father'. The noun glory is employed metaphorically in 14.3 and therefore relates to 'the light that shines ( aível) in the darkness' (5.1), which substantiates this statement. Although it has the sense of luminosity as noted earlier in 14.3.1, it is employed literally as befitting the 'only

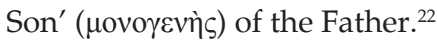

The FE also applies Jesus's 'glory' to various acts of selfrevelation (his signs: Jn 2:11; 11:4, 40). ${ }^{23}$ But the ultimate expression of glory is the complex of Jesus's death (Jn 12:16, 23,$28 ; 13: 31-32$ ), resurrection and exaltation (cf. Jn 7:39; $12: 16 ; 17: 1,5)$. This glory becomes the ultimate revelation of 'grace and truth'. In the expression then of 'glory ... full of grace and truth' (14.3.1) the addition of 'fullness' modifies 'glory'. 'When God revealed his character of "grace and truth" at Sinai, it was incomplete. Moses saw only part of God's glory (Ex 33:20-23; Jn 1:18). What here was actually 18.Barrett ([1955] 1975:138); Malina \& Rohrbauch (1998:33); Keener (2003:409).

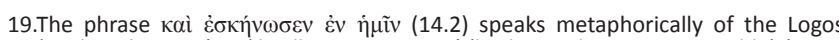
'pitching his tent' or 'dwelling amongst us' (both translations are possible) (Louw

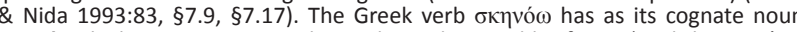
$\sigma \kappa \eta v \eta$, which means tent or tabernacle, and so could refer to 'pitch his tent' or 'tabernacle'. In the OT, it is the tabernacle and the temple that provided the special locations for such a dwelling. In Sirach 24:8-11, Wisdom, as God's immanent presence, could be said to take up its dwelling both in the tabernacle and in Zion, because the nature of that presence as glory - the Shekinah - will also be taken up in the rest of the confession of the Logos. Here the specific place of the divine upelling and presence is seen to be in Jusus rether than in the of the divine dwelling and prifincernacle or FG (cf. Jn 1:51; 2:19-21; 4:21-6; see also Lincoln 2005:104)

20.Boismard (1983:94-98); also Ridderbos (1997:55); Keener (2003:410, 417). See also the focused essay of Hanson (1976:90-101).

21.Keener (2003:410; cf. also Ridderbos (1997:51); see Boismard (1983:94-98) for a thorough discussion of the relation between Exodus 33-34 and John 1:14-18.

22.The book of Exodus narrates the experience of the Israelites of God's glory on Mount Sinai (Ex 24:16). The glory covered the mountain where Moses was summoned to approach the presence (Ex 24:16-18). Though Moses sought the glory of God, he was not permitted to see the face of God. Like the Israelites, he had but a glimpse of the glory, which was a manifestation of the presence of God (Ex 33:18-23). After the constitution of the covenant, at the Tent of Meeting God (Ex 33:18-23). After the constitution of the covenant, at the Tent of Meeting, God spoke to Moses face to face as a man speaks with his friend. On another occasion the cloud covered the Tent of Meeting and the Lord's glory filled the tabernacle so that Moses could not

23.See Ridderbos (1997:53). 'Signs' and 'glory' were already connected in the LXX. See Numbers 14:22 (with regard to Moses, cf. Ex 16:7; Nm 14:22). See also Sirach 45:3. an incomplete revelation of grace and truth through Moses was complete through Christ (Jn 1:17)' (Keener 2003:417; also Neyrey 2007:46). God provided the light for all humanity in the incarnation of Jesus as He did to all nations at Sinai through the Torah (Keener 2003:394-395).

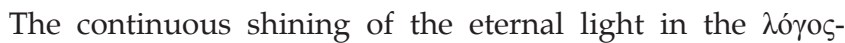

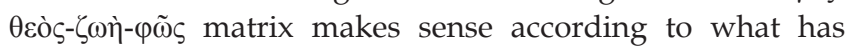
been discussed so far. ${ }^{24}$ The FE has avoided any reference to a specific historical moment of revelation. The latter comes later from verses 9-11, but more explicitly in verse 14. In the context of the second part of the prologue (verses

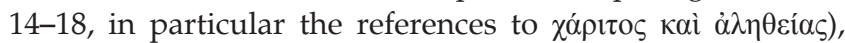
the general reference to the eternal work of the Logos in offering illumination (whether spiritual, intellectual or lifegiving) seems preferable to the incarnation. After all, the light still shines whether it is in the beginning, in the time of incarnation of the Logos, in the time of his ministry, or in the time of the reader of this text. ${ }^{25}$ From the perspective of the gospel, Bultmann's idea of ongoing revelation seems sensible. The shining of the light is both an eternal quality and a present reality. The identification of the Logos as Light and Life, the use of the present tense and the characterisation of Light (and darkness) are working towards the events of verses 14-18.

With regard to the reception of the Light, a form of synonymy occurs. In verses $14-18$, there is mention of 'beholding'

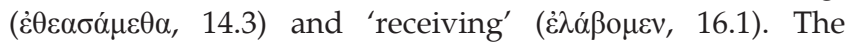
opposite to John 5:2, 10.3 and 11.2 relate to the same objects,

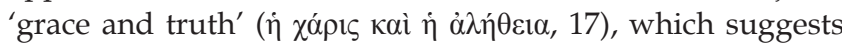
that they are also used synonymously (Bultmann [1966] 1978:76; also Petersen 1993:19). Similarly, the objects of 'receiving' are also synonymous with the designations of the Logos in verses 1-5. 'Receiving' is used of both 'grace and truth' (16.1 and 17.2) and of 'the Logos or Light' (12.1, with the antecedent noun in 9.1). In 12.1.2 this 'receiving' is even further defined by the verb 'to believe' ( $\pi 1 \sigma \tau \varepsilon v$ ov Because 'beholding' is also used in relation to the Logos (14.3), which is synonymous with 'Light', 'grace and truth' would be synonymous with the Logos as well as 'the Light'. Hence, 'grace' and 'truth' should also be capitalised, as truth is capitalised later in the FG (Jn 14:6) (Petersen 1993:19). ${ }^{26}$

Conclusion: This section reflected on the praxis of light and

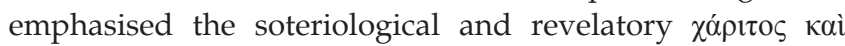
$\dot{\alpha} \lambda \eta \theta \varepsilon^{\prime} \alpha_{\varsigma}$ aspects of the incarnation of the Logos or Light,

24.In the semantic domain of the verb paives (5.1), a relative division occurs between its transitive usage denoting 'revelation' (make known, disclose, expound, its transitive usage denoting 'revelation' (make known, disclose, expound, denounce) and its intransitive usage denoting the effect of any source of light
(illuminate, shine) (Louw \& Nida 1993:173, §14.37; Phillips 2006:170-171). But the present tense seems to cause some problems for scholars. It is fairly acceptable that the present tense here shows that the light continues to have an effect throughout time which proves that it is eternal (Barrett [1955] 1975:132). However, it can be understood as a reference to the incarnation, or more metaphorically to some other revelatory event contemporaneous with either the narrative or the reading (Bultmann [1966] 1978:45-46; Ashton 1994:209).

25.Barrett ([1955] 1975:132); Schnackenburg ([1968] 1980:245); Phillips (2006:171).

26.Bultmann ([1966] 1978:18-19; 73-74) describes 'grace and truth' as 'hendiadys'. This means that one thing is said by two words. According to him, these words 'describe God's being, not 'in itself', but ... [as] the benefits in which God (or the Revealer) abounds, and which he bestows on the believer'. He also states that in the FG 'truth' has 'the meaning of divine reality itself', and that 'Truth is not the the FG 'truth' has 'the meaning of divine reality itself', and that 'Truth is not the
teaching about God transmitted by Jesus but is God's very reality revealing itself - occurring - in Jesus.' 
which is summarised in the verb $\dot{\varepsilon} \xi \eta \gamma \eta \dot{\sigma} \sigma \tau$ o in verse 18.2. Already in verse 5.1 the FE prepared his readers for what to expect further. It became clear that the 'enlightenment' (glory) of the Logos or Light is associated closely with the glory of God at the Tent of Meeting (Shekinah).

\section{The darkness could not overwhelm the Light (cluster $\mathrm{h}$ )}

The previous section emphasised the enlightenment of

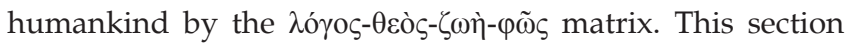
investigates the denotation that the world or his own did not accept the Logos or him or the Light.

\section{Semantic relations}

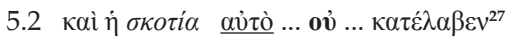

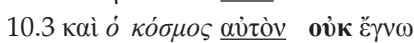

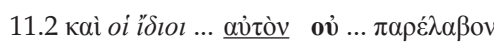

The notion of light leads to a significant contrast between Light or light and darkness in verse 5 . The reference to

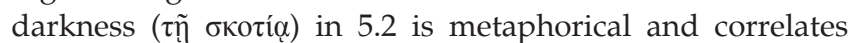
with the unbelievers as also referred to metaphorically in

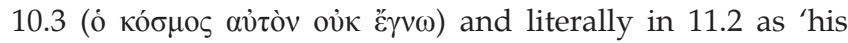

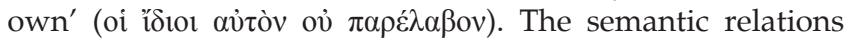
between the expressions in 5.2, 10.3 and 11.2 refer to the same act, namely that of 'not recognising' (ov̉к है $\gamma v \omega$ ) or 'not accepting' (ov $\pi \alpha \rho \varepsilon \dot{\lambda} \alpha \beta$ ov) the Light. The act or concept is the same although referring differently to two diverse subjects. The first one refers to the world ( $\dot{o}$ кó $\sigma \mu \varsigma$ ), and the second to the Jews (oi i $\delta 101)$. Subsequently, there is also an antithetical relation with 12.1 ( $(\dot{\prime} \lambda \alpha \beta \mathrm{ov})$, which comprises the opposite of 11.2 (ov̉ $\pi \alpha \rho \varepsilon ́ \lambda \alpha \beta o v$ ) and forms a chiasmus with 11.2 (cf. Schnackenburg [1968]1980:247).

Interpretation of the semantic related texts: This section, which focuses on text references in the first part of the prologue, examines the negative (negations ov̉, ov̉к, ov̉) response to the incarnation. Antithesis such as that in John 5:2 was a typical rhetorical form in both Greek and Jewish thought. ${ }^{28}$ This was particularly relevant and applicable in an environment where the language implies a sort of moral dualism, as here in the prologue. Darkness appears as a negative symbol in most ancient literature, including later Jewish texts. The struggle between light and darkness is also evident in the Dead Sea Scrolls (1QS ${ }^{29}$ 3.17-26). There the conflict between the two is a salient element, and darkness seems to hold the upper hand in the world (cf. 1QS 3.24; 11.10; $\left.1 \mathrm{QM}^{30} 13.11-12 ; 15.9\right)$. The language of John 1:5 indicates some sort of conflict between light and darkness, although the nature of the conflict is disputed. Darkness could not 'apprehend' or 'overtake' the light (cf. 1QS 13.1416), whether by comprehending it (grasping with the mind)

27.Phillips (2006:172-174).

28.See Keener (2003:386) for occurrences and examples. See also Smalley (2002: 19-20) for a brief discussion.

29. Refers to the Community Rule (1OS) which was previously referred to as the Manual of Discipline (in Hebrew Serekh ha-Yahad). See also the section 'Of the two spirits in man'.

30.The War of the Sons of Light Against the Sons of Darkness is a manual for military organisation and strategy that was discovered among the Dead Sea Scrolls. It is also known by the names War Rule, Rule of War and War Scroll. or by overcoming it (grasping with the hand). The device of playing on different senses, or different terms spelled the same way, 'was a rhetorical device that some rhetoricians called traductio' (Keener 2003:387). It seems that the FE may have adapted similar language in John 1:5. To the extent that the verb tense indicates a specific historical application beyond its general application to history, the past action will be more relevant and applicable. Consequently, the

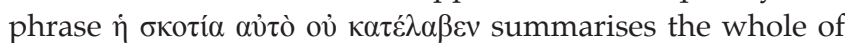
Jesus's incarnate ministry. Then the darkness implies Jesus's opposition amongst the 'world' in general (10.3), and the 'Jews' in particular (11.2). Hence, the reference to darkness ( $\dot{\eta}$

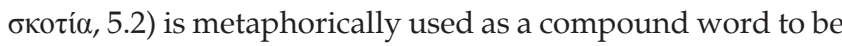
explained later to be the 'world' (10.3) and the 'Jews' (11.2). ${ }^{31}$

In verse 10.3 the FE refers to Jesus's rejection in a generic sense as 'the world did not know' Jesus (ov̉ है $\gamma v \omega, 10.3$ ), even became hostile to him (Jn 15:18-19; 17:9-6). For the FE, this was all part of the cosmic conflict of light against darkness (Burridge 2007:295). In the rest of the FG, this world included the initially ignorant Gentiles (Jn 4:42). ${ }^{32}$ They also obviously remained an object of his mission (Jn 3:16-17; 4:42; 6:33, 51). ${ }^{33}$ In the OT too, there were those who did not know God, who rejected him (1 Sm 2:12; Is 1:3; Jr 4:22; Hs 5:4). The Jewish tradition likewise claimed that God offered his Torah - his Word - to all nations; nevertheless, the nations rejected it because they wished to continue in their sins (Keener 2003:397). According to the FG, the world did not know the Father (Jn 16:3), the Spirit (Jn 14:17); the believers are depicted to be not from this world (Jn 3:3, 8) ${ }^{34}$ The lack of knowledge of Jesus by the world is also echoed in John 1:26 and 2:9.

This enigmatic and painful fact that the Logos met with rejection in the world is expressed almost paradoxically in

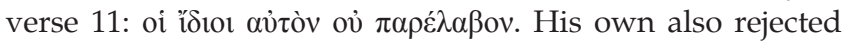
him (ov̉ $\pi \alpha \rho \varepsilon ́ \lambda \alpha \beta o v, 11.2$ ). ${ }^{35} \mathrm{He}$ was rejected by the Jewish

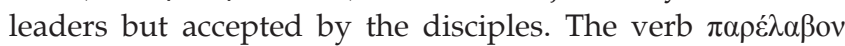
(in comparison with 12.1) used with the negation ov is used to imply deliberate rejection (Jn 3:32; 5:43; 12:48). This verse introduces the inadequate response of most of ethnic Israel to Jesus. It echoes the fact that the Jewish traditions of various dates emphasised the difference between Israel and the nations in the Exodus event and in other aspects (Keener 2003:398). ${ }^{36}$ The chosen people of God (the Jews), who celebrated Torah, rejected the Torah in the flesh, which

31.Throughout the $\mathrm{FG}$, Jesus experiences opposition from two sides: in the first part of the Gospel from the 'Jews' (Jn 2:13-22; 5:16-18; 7:1-2, 30-32; 8:37, 59; 10:31; 11:46-54), and in the second part from the 'world' (see, for example, Jn 14; 15:1819; $16: 33$ ).

32.Schnackenburg ([1968]1980:258) has a different viewpoint.

33.Augustine (n.d.:§11).

34.See Dodd (1963:156) and Keener (2003:395) for related Jewish and Hellenistic expressions.

35.According to Brown (1966:10), the neuter may refer to the land, and the masculine to the people. See also Schnackenburg ([1968]1980:259); he opts for 'property', which refers to the people.

36.In that Keener (2003:398) wrote 'the pillar of fire gave light to Israel alone; the revelation at Sinai frightened the whole world until Balaam explained that God was revealing himself to his children; multiple angels crowned each Israelite at Sinai. Even after their initial acceptance, Israel continued to obey Torah, in contrast Sinai. Even after their initial acceptance, Israel continued to obey Torah, in contrast
to the nations around them, and in many traditions God accepted their obedience as very satisfactory'. 
constitutes a central ecclesiological motif throughout the FG (Keener 2003:399). The FE introduces this 'foundational irony of the gospel ... at the outset' (Culpepper 1983:169). The rejection of Israel presents a crisis. For the FE the receiving

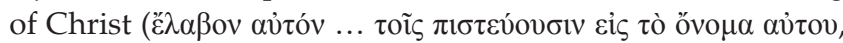
Jn 1:12) is essential to salvation. His own is now defined as those who pay attention to his message (Jn 10:3-4), and those who were in a true covenant relationship with him. Here the message of the FE conflicts with the abovementioned Jewish tradition (Keener 2003:399).

Hence, the differentiating function of light is related to the worldly distinction between day and night, which serves as an analogy for the Light shining in the world in Jesus. For the FE, light is first differentiated from darkness, which refers to the world without Light (Jn 1:1-5, 9-13). But, the shining of the Light or light also differentiates the followers of the Light from those who do not follow. To say that Jesus is the Light that shines or comes into the world is metaphorical. ${ }^{37} \mathrm{He}$ is the light in this world who also gives the 'Light of Life' (Jn

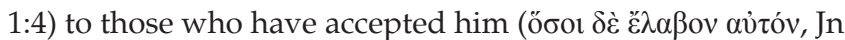
$1: 12 ; 8: 12 ; 9: 5 ; 12: 46)$. But the coming or shining of the Light produces differentiation between those who have the 'Light of Life' and those who do not (Jn 3:13-21) (Petersen 1993:75). The FE contrasts those who 'walk in darkness' with those who 'come to the Light' and in the process renders these expressions synonymous with the synonyms associated with the contrast between 'receiving' and 'not receiving' (Jn 3:17$21 ; 8: 12 ; 12: 35-36,46) .{ }^{38}$ In fact, in John 12:36, believing in the Light makes it possible to become 'children of light', which appears to be a metaphorical synonym for the metaphor

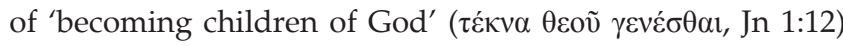
(Petersen 1993:20-21).

Conclusion: This section discussed the struggle between light and darkness. All references occur in the first section of the prologue. In verse 5.2, the FE uses the noun бкотí $\alpha$ as a compound word to refer to both the 'world' and 'Jews', Jesus' opponents. Those who 'walk in darkness or non-acceptance' (11.2), are contrasted with those 'who come to the light'.

37.Petersen (1993:75) firstly agrees that the FE uses "light' as a moralistic metaphor but then adds that 'to say that Jesus himself is the Light that shines/comes into the world is not metaphorical' (italics in original). He correctly verifies this statement because Jesus 'is' the 'Light of this world' who also gives the 'Light of Life' to those who come to him (Jn 8:12; cf. 1:4; 9:5; 12:46).

38.The contrasting terms in the prologue are rarely semantic opposites or antonyms, such as 'light' and 'darkness' (see Petersen 1993:20; Lyons 1977:270-290; Palmer 1981:94-100). The FE distinctively creates negative opposites by grammatically negating the positive term or expression, as in his contrast between 'receiving' and negating the positive term or expression, as in his contrast between 'receiving' and
'not receiving'. The occurrences of the negative opposites are quite notable and 'not receiving'. The occurrer

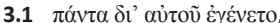

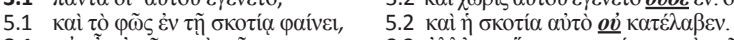

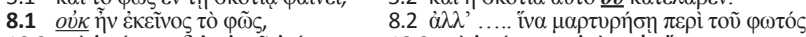

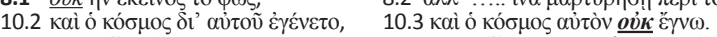

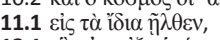

13.1 oî ob̉

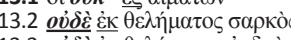

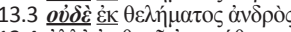

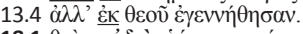

18.1 Ө

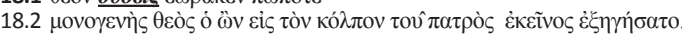

The FE also uses a negative statement followed by an adversative $(\dot{\alpha} \lambda \lambda \alpha, 8.2 ; \kappa \alpha \dot{i}$, $10.3 ; 11.2)$. In verse 18 he starts with a negative statement and continues positively

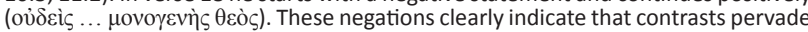
the thinking of the FE. He uses them economically in the context of the Johannine the thinking of the FE. He uses them economi
dualism that runs throughout the gospel.

\section{The Light enlightens - brings salvation (cluster b)}

This subsection investigates the features of the acceptance of the Logos or Light.

\section{Semantic relations:}

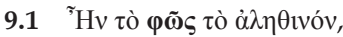

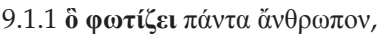

A

12.1 ö $\sigma o l \delta \dot{\varepsilon} \ddot{\varepsilon} \lambda \alpha \beta o v$ av̉ióv,

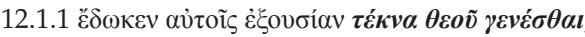

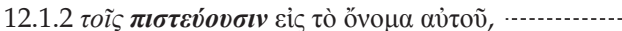

13.1 oî ở火 $\underline{\underline{\varepsilon} \xi \alpha i \mu \alpha ́ \tau \omega v}$

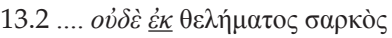

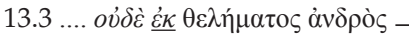

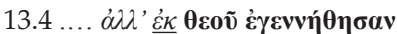

Verse 9 prepares the reader for what is going to follow in verses 12 and 13 . Verse 12 forms a chiasmus. In the parallelism between 12.1 and 12.1.2, the first one states with greater precision the meaning of the second: 'those who accepted him' are 'those who believe in his name' ${ }^{39}$ Verse

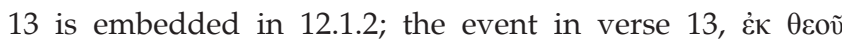
$\dot{\varepsilon} \gamma \varepsilon v v \eta \dot{\theta} \eta \sigma \alpha v$, describes how a person becomes a child of God ( $\varepsilon \dot{\kappa} \kappa v \alpha \theta \varepsilon \circ \tilde{v} \gamma \varepsilon v \varepsilon \dot{\varepsilon} \sigma \alpha$ ) through faith. Verse 12 describes the human responsibility, and verse 13 God's act in the process of salvation. ${ }^{40}$

Interpretation of the semantic related texts: In verse 9 the FE states that the true light 'enlightens every person' (cf. 4.2) and thus describes the light in its fullness and universality. By this statement we cannot infer that every individual is in fact enlightened by the light (cf. 5.2 and 10.3). What is true is that the light is for everyone and it is only by the light alone that a person can live (cf. Jn 8:12; also 1:12, 13) (Ridderbos 1997:43).

Verse 12 expresses the positive response to the incarnation or reception of the Logos or Light and previews the second part of the FG where Jesus is portrayed with those who did receive him. They are a new group who can be called 'his own' (Jn 13:1). According to 12.1.1, it seems that the Logos

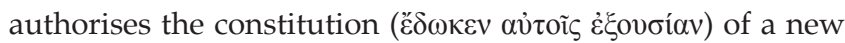
people of God, those who walk in the light (Jn 3:21; see also 1 Jn 1). He puts people in the position of being able to become children of God. ${ }^{41}$ They are contrasted to both, the world and Israel, by the adversative $\delta \grave{\varepsilon}$ (but) (Keener 2003:399). ${ }^{42}$

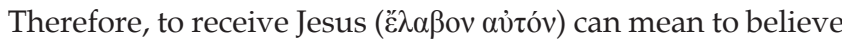
in him as the Logos, Life, Light, God, or God's agent (Jn 12:1,

39.Although Brown (1966:11) is reluctant to identify the prologue's structure as chiastic, he notes the correspondence between these phrases.

40.Bear in mind that although there is a human responsibility of accepting Jesus

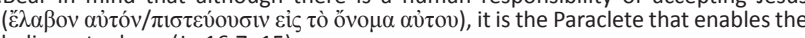
believer to do so (Jn 16:7-15).

41.See John 8:41-47 about those who can validly claim to have God as their Father this designation for God's people occurs also in John 11:52. The diminutive form 'little children' is used in John 13:33; this form is found more frequently in the Johannine epistles: 1 John 3:1, 2, 10; 5:2.

42.Verses 10 and 11 form a parallelism:

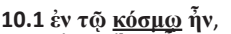

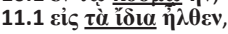


$5-43,48 ; 13: 20),{ }^{43}$ or in his name. ${ }^{44}$ To believe in Jesus's name is not different from believing in him; or to entrust oneself to who he is and what he has done (Lincoln 2005:103). One must believe that he bears the divine name given to him by God (Jn $17: 11,12) .^{45}$ This can be verified by the facts stated elsewhere in the FG that Jesus comes in his Father's name as his agent (Jn 5:43; 12:13; 17:11-12) and works in the Father's name (Jn $12: 28 ; 17: 6,26)$. His followers are to believe in Jesus's name (Jn $1: 12 ; 2: 23 ; 3: 18)$, receive life in his name (Jn 20:31), ask in his name (Jn 14:13-14; 15:16; 16:23), and expect to suffer for his name (Jn 15:21). Apart from John 2:23 'believing in his name', this reference appears only in two strategic passages. The first appears in the prologue (verse 12) and the last reference to faith (by implication) is at the end of chapter 20 (Jn 20:31) (Keener 2003:400). The reference in the prologue agrees with John 20:31 and states that those who accept Jesus or Light and believe in his name become 'children of God' (ő $\sigma o 1 \delta \grave{\varepsilon}$

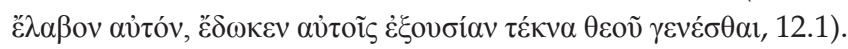
The author of 1 John also calls those who believe in his name 'children' in typically Johannine idiom (1 Jn 2:1, 12, 13, 18, 28; $3: 7,18 ; 4: 4 ; 5: 21 ; 3$ Jn 4$){ }^{46}$ These children of God are also called 'children of light' (

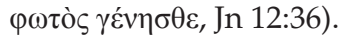

Their authority ${ }^{47}$ ( $\dot{\varepsilon} \xi o v \sigma i ́ \alpha v$, Jn 12:1.1) to become God's children (Jn 1:12) emphasises divine authorisation to become what no human effort can accomplish (Jn 5:27; 10:18; 17:2; 19:10); only the revealer from above or the Light can inaugurate them into the world above (Jn 3:13-18). Becoming children of God entails receiving the divine nature or character of Jesus. This contrast between divine authorisation and human ability is clear in verses $12-13$ of the prologue. Outside the prologue, differentiation is evident when Jesus claims to be the light that has come into the world (Jn 1:9-13; 3:19; 8:12;

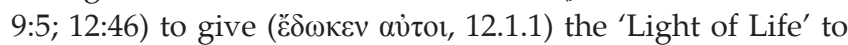
those who 'follow' or 'believe in' that Light (Jn 8:12), which enables them to 'become children of the Light' (iv $\alpha$ vioi

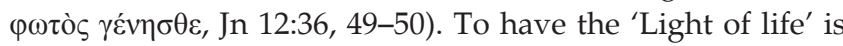
synonymous with 'children of the Light' and 'children of

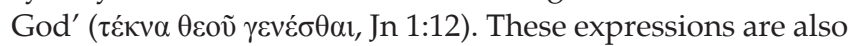
synonymous with being 'born from above' ( $\gamma \varepsilon v v \eta \theta \tilde{n}$ ö $v \omega \theta \varepsilon v$,

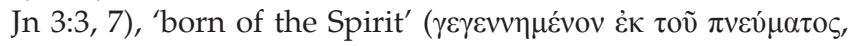

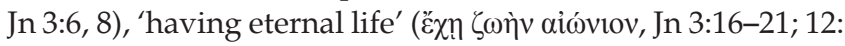
44-50), and knowing 'the only true God, and the one whom

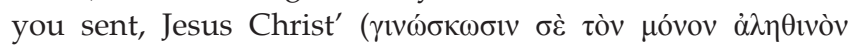

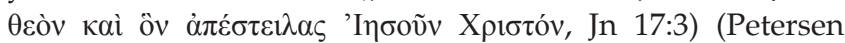
1993:73).

43. Whatever the other associations might be, the vocabulary is rooted in the vocabulary of early Christian soteriology (Col 2:6)

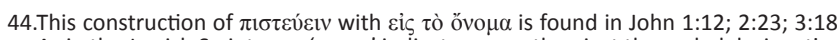
As in the Jewish Scriptures, 'name' indicates more than just the verbal designation of a person. It signifies all that a person represents.

45.See Brown (1966:11, 533-538); and Keener (2003:399) for the possibility that the name of Jesus may be 'I am'. The reference to 'name' was a circumlocution for God.

46.Keener (2003:400-402) briefly describes how different segments of Mediterranean antiquity read 'children of God' in different ways. He rounds it off with the reference that it is hardly comparable with the usage of the FG. The FE usage appears closer to Palestinian texts. See also Psalms of Solomon (17:27). The Wisdom of Solomon to Palestinian texts. See also Psalms of Solomon (17:27). The Wisdom of Solomon
also declares both the righteous $(2: 13,16,18 ; 5: 5)$ and Israel $(11: 10)$ to be sons of God in The New Jerusalem Bible.

47.Barrett ([1955] 1975:136); Brown (1966:11). See also 1 Cor 8:9 for a translation of 'freedom' or 'liberty'.
The Light's luminosity, during the incarnation, is only perceivable to the believers (Jn 1:8-9; 12:36) and is formulated by the FE in terms of the Logos's glory, which is manifest in Jesus (Jn 1:14; 2:11). In the context of the prologue, 'glory' $\left(\delta \xi^{\prime} \xi \alpha, 14\right)$ refers to the luminosity of the Logos or the true $e^{48}$ Light that pre-existed (Jn 1:14;12:41) before the creation ( $\pi \alpha$ v $\tau \alpha$

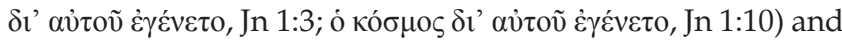
to which it returned in Jesus's glorification (Jn 17:1, 5, 24). During the incarnation, this glory was manifest 'to believe'

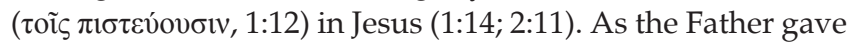
Jesus his 'glory', so did He give it to the followers of Jesus, so that they may be united both with one another and with the Father and the Son, just as the Father and the Son are themselves united (Jn 17:11, 20-23). In the 'world below' the Father, Son, and the Father's children are differentiated from one another, but the ultimate state envisioned by the FE is an undifferentiated one as envisioned in the notions of 'Light', 'glory' and 'Life' (Petersen 1993:74). ${ }^{49}$

Conclusion: In this final section (verses 12-13) the FE presents what happens to those who come to the Light. For him 'children of the Light' is synonymous with 'children of God' and 'those who believe in Jesus's name'.

\section{Conclusion}

From this research it became evident how comprehensively the light metaphor is embedded in the Johannine prologue and also how many features could be attached to the light metaphor. This investigation also attempted to show how the light metaphor connects major themes in the prologue and seems to be one of the key theological themes in the prologue. $^{50}$

It has been pointed out how the incarnation of the Logos is depicted as a new Sinai theophany; it fulfils the salvation (enlightenment) started with the Shekinah in the wilderness. Whilst shining in the world, the light produces differentiation

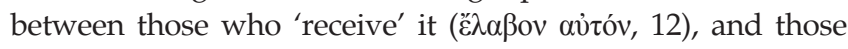

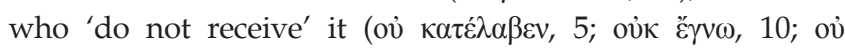

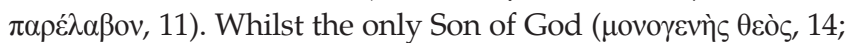
18 ) is in himself undifferentiated, he is also in himself the place of differentiation. When the Son entered the world it is referred to in the language of differentiation, such as 'the light shines in

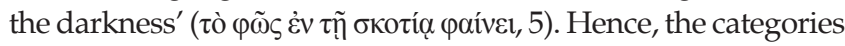
of 'differentiation' and 'non-differentiation' are analytical categories that describe the main soteriological functions of the light conceptual system (cf. Pietersen 1993:72-79).

It also became evident that the concept of light, as used in the prologue and the FG, belongs to both the sphere of pure contemplation and praxis. It has an ethical

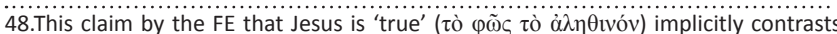
him with what is not true or unreliable (Neyrey 2007:43). Jesus is also 'true' bread from heaven (Jn 6:32) versus Moses's manna; his judgement is 'true', whereas his audience judges according to appearances (Jn 8:16); he is also the 'true' vine (Jn 15:1).

49.See John 12:31-32; 14:2-3, 19-20; 17:24.

50.In the first article of this combination the focus was on the references to the light metaphor prior to the incarnation. In this article the focus is on the references to the light metaphor during and after the incarnation. 
import (cf. Avis 1999:54). The FE employs metaphorically the imagery of light (vehicle) to describe the Logos (tenor), and to emphasise his salvific function.

\section{Acknowledgements Competing interests}

The authors declare that they have no financial or personal relationship(s) which may have inappropriately influenced them in writing this article.

\section{Authors' contributions}

Both D.G.VdM. and P.Y.A. contributed to this article. D.G.VdM. provided his experiential inputs and revised the final product and was also responsible for the final editing, finishing touches and rounding off of the article.

\section{References}

Ashton, J., 1994, Studying John: Approaches to the Fourth Gospel, Clarendon Press, Oxford.

Augustine, n.d., Tractate 2 (John 1:6-14), viewed 09 November 2011, from http:// www.newadvent.org/fathers/1701002.htm.

Avis, P., 1999, God and the creative imagination: Metaphor, symbol and myth in religion and theology, Routledge, New York.

Barrett, C.K., [1955] 1975, The Gospel according to St John. An introduction with commentary and notes on the Greek text, SPCK, London.

Boismard, M.E., 1953, St. John's Prologue, transl. Carisbrooke Dominicans, Blackfriars, London.

Boismard, M.E., 1983, Moses or Jesus. An essay in Johannine Christology, Fortress Press, Minneapolis.

Borgen, P., 1970, 'Observations on the Targumic character of the Prologue of John', NTS 16, 288-295. http://dx.doi.org/10.1017/S0028688500012558

Brown, R.E., 1965, 'Prologue of the Gospel of John: John 1:1-18', Review \& Expositor 62(4), 429-439.

Bultmann, R., [1966] 1978, The Gospel of John: A commentary, transl. G.R. Beasley Murray, Blackwell, Oxford.

Burridge, R.A., 2007, Imitating Jesus: An inclusive approach to New Testament ethics, Eerdmans, Grand Rapids, Mich.

Cahill, P.J., 1976, 'Johannine Logos as center', QBC 38(1), 54-72.

Culpepper, R.A., 1981, 'The pivot of John's Prologue', NTS 27, 1-31. http://dx.doi. org/10.1017/S0028688500010237

Culpepper, R.A., 1983, Anatomy of the Fourth Gospel: A Study in Literary Design, Fortress Press, Philadelphia. PMCid:370365

Deeks, P.W., 2002, 'The light of glory: An exposition of the Prologue of John's Gospel', Churchman 116 (2), 113-126.

De Wolf, L.H., 1960, 'Proclaiming Jesus Christ as Light', Encounter 21(1), 43-51.
Dodd, C.H., 1963, Historical tradition in the Fourth Gospel, Cambridge University Press, Cambridge. http://dx.doi.org/10.1017/CBO9780511554919

Hanson, A.T., 1976, 'John i.14-18 and Exodus xxxiv', New Testament Studies 23, 90-101. http://dx.doi.org/10.1017/S0028688500008420

Hildegard, S. \& Newman, B., 2003, 'Commentary on the Johannine Prologue', Theology Today 60(1), 16-33. http://dx.doi.org/10.1177/ 004057360306000103

Hooker, M., 1970, 'John the Baptist and the Johannine Prologue', NTS 16, 357-381. http://dx.doi.org/10.1017/S0028688500014065

Keener, C.S., 2003, The Gospel of John. A commentary, Vol. 1, Hendrickson Publishers, Peabody, Mass.

Köstenberger, A.J., 2004, John. Baker exegetical commentary on the New Testament, Baker Academic, Grand Rapids, Mich.

LaMarche, P., 1997, 'The Prologue of John (1964)', in J. Ashton (ed.), The Interpretation of John, pp. 47-66, T \& T Clark, Edinburgh.

Lincoln, A.T., 2005, The Gospel According to St John, Black's New Testament Commentary, vol. 4, Continuum, New York.

Louw, J.P. \& Nida, E.A., 1993, Greek-English Lexicon of the New Testament based on semantic domains, United Bible Societies, Cape Town.

Lyons, J., 1977, Semantics, Cambridge University Press, Cambridge. http://dx.doi.org/ 10.1017/CBO9780511620614, http://dx.doi.org/10.1017/CBO9781139165693

Malina, B.J. \& Rohrbauch, R.L., 1998, Social-Science commentary on the Gospel of John, Augsburg Fortress Publishers, Minneapolis.

Miller, G.L., 1977, 'Life and the glory: Some reflections on the Prologue to John', Brethren Life and Thought 22(4), 211-226.

Mullins, M., 2003, The Gospel of John. A commentary, The Columba Press, Dublin.

Neyrey, J.H., 2007, The Gospel of John, Cambridge University Press, Cambridge.

Palmer, F.R., 1981, Semantics, Cambridge University Press, Cambridge.

Petersen, N.R., 1993, The Gospel of John and the sociology of light: Language and characterization in the Fourth Gospel, Trinity Press International, Valley Forge.

Phillips, P.M., 2006, The Prologue of the Fourth Gospel. A sequential reading, Library of New Testament Studies 294, T \& T Clark, London.

Psalms of Solomon, viewed 08 November 2011, from http://www.sacred-texts.com/ bib/poly/pss017.htm

Riches, J., 2005, 'Worship resources. Exegetical reflections on lectionary readings: Johannine Prologue', Expository Times 117(2), 69-73. http://dx.doi. org/10.1177/0014524605059892

Ridderbos, H., 1997, The Gospel of John. (A theological commentary), transl. J. Vriend, Eerdmans, Grand Rapids, Mich.

Robbins, V.K., 1996, Exploring the texture of texts: A guide to socio-rhetorical interpretation, Trinity Press International, Valley Forge.

Ryan, W.F., 1963, 'John's hymn to the world', Worship 37(5), 285-292.

Schnackenburg, R., [1968] 1980, The Gospel According to St John, vol. I, transl. K. Smyth, Burns \& Oates, London.

Smalley, S.S., 2002, 1,2,3 John, Word Biblical Commentary, vol. 51, Word, Incorporated, Dallas.

Staley, J., 1986, 'The structure of John's Prologue: Its implications for the Gospel's narrative structure', CBQ 48(2), 241-264.

Van der Watt, J.G., 1995, 'The Prologue of John's Gospel: The historical Jesus introducing divine grace', Westminster Theological Journal 57(2), 311-332.

Waetjen, H.C., 2001, 'Logos pros ton Theon and the objectification of truth in the prologue of the Fourth Gospel', CBQ 63(2), 265-286. 


\section{Addendum 1}

\section{A proposed chiastic structure}

\section{Themes semantic relations}

\section{Speech is in the first person}

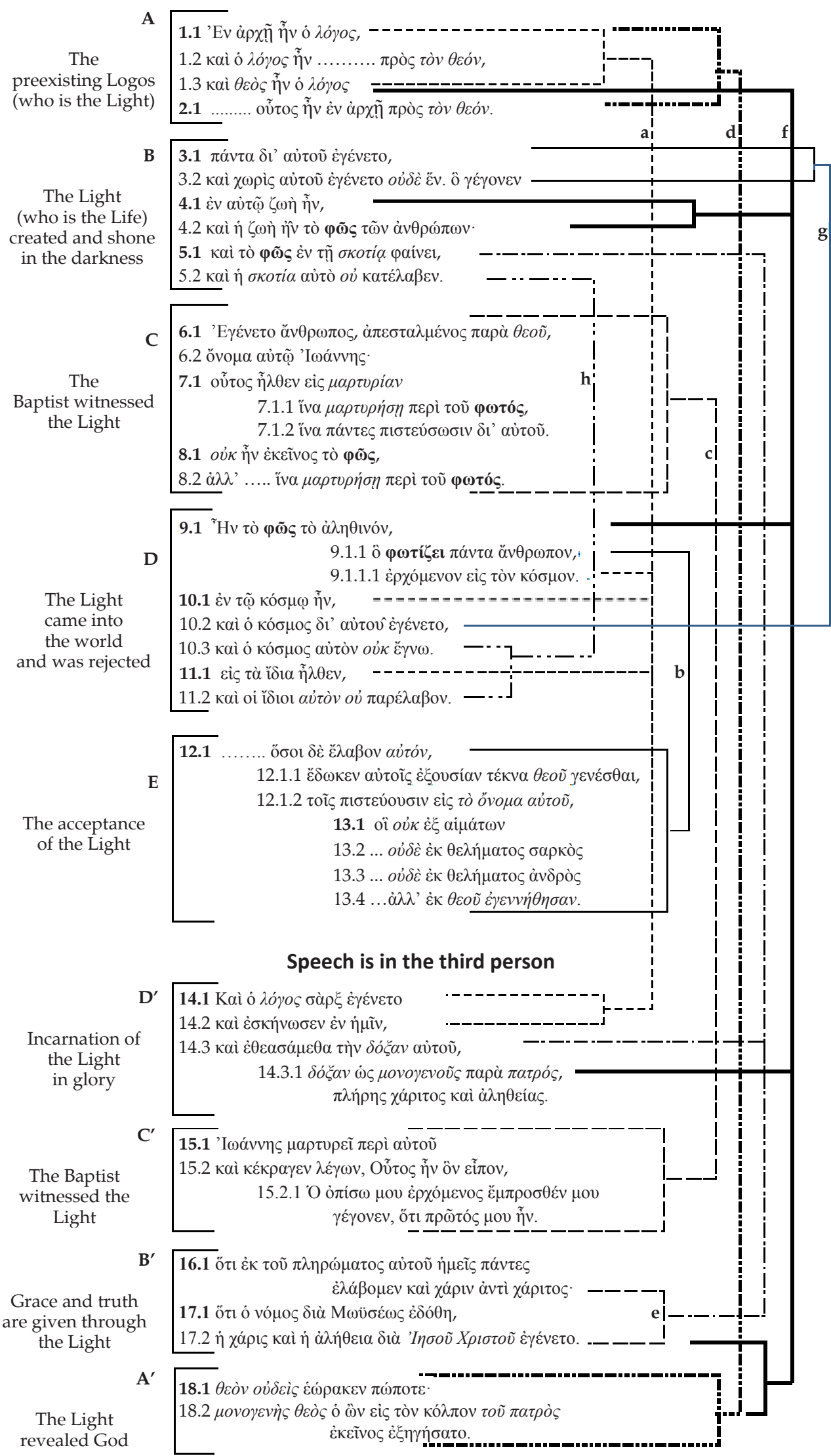

